\title{
The Music Complex of Emperor Yang of Sui Dynasty
}

\author{
Shuyue Ding \\ The Media School \\ Mianyang Normal University \\ Mianyang, China 621000
}

\begin{abstract}
The poems written by the emperor Yang of Sui Dynasty show different characteristics in different periods, which are closely related to the special background of his life. The elaboration on the relations between the Emperor yang and the music in this paper clearly embodies his outstanding talent in music. Emperor Yang is a tyrant in people's view, but his contribution to the development of music art is indelible. He has a unique way in dealing with the relations between ethnic minorities by use of music, which is worth research.
\end{abstract}

Keywords-Emperor Yang of Sui Dynasty; music thought; music creation; ethnic relations

\section{INTRODUCTION}

In the history of China, there are many such emperors as Cao Pi, Tang Xuanzong, Li Yu, Song Huizong, who are good at poetry and poems, proficient in music rhetoric. The emperor Yang of Sui Dynasty is just one of them, and has been recognized the tyrant matched with the Second Emperor of the Qin Dynasty in the history. "The bamboo is exhausted to write his crimes, the water of the East China Sea exhausted to wash his evil"'[1] is a true portrayal for him. Emperor yang can be described as tyrant among the ancient emperors, but he is one of a handful of outstanding talents in music in the Chinese history. Sui Dynasty (AD 581-618) has a short life, and about its demise, there are many reasons. The author talk about only his creation of music poetry and his thoughts on music, and his application of music function in solving the relationship among the ethnic minorities, especially that among the Western tribes, in order to make readers clearly understand his contribution to the music. It can be said that the tyrant is actually a pioneer in promoting the national harmonization by use of music in the history.

\section{HidDEN NATURE: TWO DIFFERENT KINDS OF WORKS AND WORKS STYLES}

Emperor Yang has his music poetry creation of different styles in different periods, with the dividing line when he took the throne. According to the "The Book of Sui", it is recorded: " handsome and smart, specially loved by emperor Gaozu".[2] The ancient throne is often hereditary to the eldest son of emperor, but Emperor Yang of Sui (the second son of Emperor Wen of Sui, Yang Jian, also known as Yang Ying, with a infant name $\mathrm{A} \mathrm{Ma}$ ) who is not the eldest son eventually took the position of prince, which is inseparable with his smart and clever conditions. "The Book of Sui" records: "when visiting him, Gaozu finds his music instruments mostly are strings- broken and covered with dust, so Gaozu thinks he does not like prurience, and trusts him. In fact, Emperor Yang of Sui loves music and his music poetry creation has different styles in different periods" [2]

Before ascending the throne, Emperor Yang appreciates music strictly according to the Yayue (elegant and pure music) system, because Yayue can be used to proclaim the merits and virtues in the worship ceremony, to consolidate the imperial power and serve the politics. In Volume 15 of "The Book of Sui -Record of Music", it is said: "first, Gaozu sent the civil assistant minister Li Yuanhua, and provincial Neishishen Lu Sidao, et al. to list twelve temple songs, ordered people Cao Miaoda from Qile to teach music, instead of the song of Zhou. the first seven-character octave for welcoming the God include the 'Yuanji Song', the six-character octave for ceremony of ascending the throne, include the 'Qingbei Music', the fivecharacter octave for completion of sending the God include the 'Xingtian Song'. Hong and others is changed and integrated into the Bell-Temperament, and the $\mathrm{Ci}$ is from imperial order and is not changed. In the sixth year of Renshou period, Emperor Yang just took the position of prince, making enjoyment in the Tai temple, and when hearing it, he disagreed with it, and then suggested that 'the song of temple for worshipping has too many and foppish words, not suitable for proclaimation of merits, so please change it and make another decision.' So the imperial order is taken to send the Libu Shangshu (minister of personnel), Qizhang Gonghong, Kaifu Yitong Sansi, Taizi Xima Liu Guyan, Mishu Cheng, Shetaichang Shaoqing Xu Shanxin, Neishi Sheren Yu Shiji, Libu Shilang CaiZheng et al. to make detailed check and set up Yayue song."[3] From this, we can find the Emperor Yang of Sui made the creation of music strictly in accordance with the Yayue system before becoming the emperor. His literary and artistic creation is not apt to flighty and extravagant style, that is the sound of gorgeous style. In the Volume 76 "Preface of literary biography" of the "book of Sui", it is said, "at his early stage of literary and artistic study, the theory of non-flighty and extravagant style exits, and when ascending the throne, Emperor Yang changed this style. In his "Letter to Yue Gong", "imperial decree to build East Capital", "poem of accepting worship in the midwinter" and "plan to make horse drink in the Great Wall Cave" All have Yayue style in coexistence, attributed to the decrees and regulations. Although there is the meaning of pruriency in them, there is no profligate word. So the writers follow him and take it as the model. [4] At the early stage of Emperor Yang period, music poetries are mostly of elegant style, which is inseparable with the trust of Emperor Wen of Sui for him when he early entered the throne. 
The later music creation style of Emperor Yang has very difference from his early creation style, which is mainly shown as: it is blended with the soft and slow music of prurient intent", that is the so-called " romantic music", such as "Song of Jiangling female": "rain comes from the sky, the water flows over under the bridge. Pick up the waistband of girl and connect the two with the heart knot". [5] This poem describes a young girl from the scene, with flirtatious meaning, which can be said as the " romantic music" at that time; and the "To Zhang Lihua": there is no important thing to do for meeting you only because hearing of you for a long time; with a good look when seating, this is really a good acquaintance. [6]

From the poetry, we can find Emperor Yang's compliment for Zhang Lihua. Compared with the early poems, this style is very different. In addition, there are many such poems, like "Jiangdu Palace Music", "Grant to court maid" that all have frivolous and gorgeous composition. Obviously, compared with the early Yayue music, the style of these works is very different.

His later works is created for pleasure of beauty, or for flirtatious funny, with great hedonistic fatalistic ideas, full of strong emotional desire, accepting the concept and way of life of "resist the ritual, follow the sexual desire" of the landlord family. "Zizhi Tongjian - the Sixth Year of Great Cause of Emperor Yang " records, "ride horse to travel the West park, followed by thousands of court maids in the good moonlight, write the song of "Tour in Moonlight" and play it on the horse." [7] Emperor Yang often led many court maids to play his "Tour in Moonlight" in the moonlight to enjoy the beauty and make amusement. And the Volume 15 "Record of Music" of the "Book of Sui" records, "(Emperor Yang) writes greatly the romantic chapters, with very lascivious and gorgeous words. He orders Yuezheng Bai Mingda to create new music, including "Long Live Music", "Hidden Hook Music", "Music of Meeting in Double Seventh Festival", "Music of Throwing Pot", "Wuxi Tongxin Ji", "Yunv Xingshang", "Shenxian Liuke", "Zhizhuan Xuming", "Dou Jizi", "Dou Baicao", "Fan Longzhou", "Huan Jiugong", "ChangLehua", "Shier Shi” and so on, depressive, low-spirited and sorrowful. Emperor Yang is pleased for this and said to his favorite officials, "playing much music as reading many books. When reading books as many as possible, you can write books, and when playing music as much as possible, you can create music, and the truth is same for both.[4] Emperor Yang later ordered musicians to create a large number of music, and the music has a very different style from that in the previous period. This shows that Emperor Yang has greatly changed his appreciation standard at the late stage. The author thinks that Emperor Yang is actually a typical flirtatious person, indulged in wine and prostitutes, but he depressed his nature before he took the position of prince, forced to take on an honest and eager appearance to cater the trust of Emperor Wen of Sui and his mother; and once he won the throne, he could no longer bear the sense of repression, and then had a relieved joy, so he began a wanton squandered in the material and was indulge in sensuality, and he created some romantic poems to release his depression in the spirit.

\section{INGENUITY: UsE Music ART TO DEAL WITH NATIONAL AFFAIRS}

Emperor Yang has a great contribution to the music development of China, especially in the use of music in dealing with ethnic relations, and he has prominent merits among the ancient emperors.

At the beginning of state establishment, Sui faced a great threat of the minorities around it. The Turkic in the north as the main, associated with Tuyuhun and Goryeo, together formed a huge encirclement for the Sui, and often violated the Sui border. In the second year of Emperor Wen reign period (AD 582), the Turkic made a massive attack with the "400 thousand bowmen", " from the Muxia gate and Stone gate, the enemy invaded Wuwei, Tianshui, Jincheng, Shangjun, Honghua and Yan'an, and domestic animals are all looted"[8] This is a serious threat to the survival of Sui. Later, Emperor Yang combined the Confucian ritual moral and music exchanges to improve the relationship between the Sui and the Western Regions. The "Book of Sui" contains, "in the 51st year of the Sexagenary Cycle, at the imperial account, prepared the instrument and set up flag, feted Qimin and his tribes three thousand five-hundred people, played Baixi music"[2] and "in the $53^{\text {th }}$ year of the Sexagenary Cycle, in the imperial Guanfengxing palace, grant cultural relics were displayed, nine pieces of music were played, Longyu Manyan music was performed, for feting King Gao Chang, and making a pet of the alien."[2] "In the 16th year of the Sexagenary Cycle, met the Barbarians, set the music of Longyu Manyan, and made different grants."[9] Obviously, these show the scene that Emperor Yang feted the minorities, in which the music is vivid and exquisite, but also received a good effect." In the "Zizhi Tongjian • the Third Year of Great Cause of Emperor Yang", it is said, "in order to flaunt Sui's superiority to the Turkic, Emperor ordered $\mathrm{Yu}$ Wenkai to set up tent that can contain thousands of people; in the 51st year of the Sexagenary Cycle, Emperor Yang set up big tent in the east of city, and arranged Yiwen to fete Qimin and his tribes and played the Sanyue music. All the Northern barbarian tribes were shocked and delighted, they rushed to the fore to offer their cows and horses of thousands. Emperor Yany granted Qimin with 20 million pieces of silk cloth, and his subordinates with different gifts. And he granted Qimin carriages and horses, provided with wind and drum music, flag and Zanbai ceremony, the scale is higher than that for vassal king." [10] These big tents that can accommodate thousands of people, and the various Sanyue music are rare for the nomadic people who never heard of before, so they have a great fear and respect of Han people. They rushed to the fore to offer their cows and horses of thousands, to show their will for friendly exchanges. Emperor Yang specially made a great rendering of music range in his northern and western patrol tours, to create grand momentum, and he implemented major popularization of music to "boast of rich music in Sui" when the minorities visited Sui, such as “the Zhou's, Qi's, Liang's, Chen's generations in the world all are music family, the people from the deacon to the plebeian all are good at music. This is very common."[11] Emperor Yang expanded the scale of music, collected national music talents, and made a great contribution to the development of music in China at that time. In addition, he also carefully 
prepared a large-scale song and dance performance in Luoyang, with very high appreciation.

"Sarira first goes to the stage, performs in the field, a minute later, jumps and arouses water full of thoroughfare, turtles and alligators as well as water insect and fish cover the ground; Large whale sprays fog to hide the sun, and suddenly becomes into yellow dragon, more than seven-zhang long, jumping out, called "Yellow Dragon Change"; on a rope with the two ends respectively tied on the two posts, two female actors dance face to face on the rope, and when meeting, brush past each other, without stopping singing and dancing; .there also is "Xia Yu lifting a tripod", a person takes wheel, stone mortar and large urn device on his the palm, lifts and plays them, and at the same time, two persons perform Daigan, playing and dancing, and suddenly they change place each other; there is the performance of "Shengao Fushan", magic artist spits fire, ever-changing, with nobody mated with it form from the year dot"[4] The exquisite performances show the Han people and ethnic minorities celebrate together. These make the minorities have their hearts captivated and would rather submit themselves to Han nationality.

Later, Emperor Yang listed such performances into system: "at the lunar month every year, every state comes to worship, staying till the 15th; outside the Duan gate and inside of Jianguo Gate, the play field spreads about 8 li. All officials put up shed on both sides of road, watching the performance from dusk until dawn. Actors all wear colorful and beautiful clothing. The singers and dancers mostly are in women's dress, with pendants and rings as well as flower and feather ornaments, almost totaling thirty thousand people."[4] The gorgeous scenes continue year after year, and are very attractive. After Emperor Yang made the west tour, in the sixth year of the great cause, "except Turkic Qimin, all the states kings personally come to congratulate," and the singing and dance reached the peak this year; in Luoyang: "Baixi (general title of various ancient folk performances) is played on Tianjin Street, all the strange skills get here together. Luxuries and appreciation articles, grand ornaments and clothes, all made with pearls and jade or gold and silver, or brocade, linen fiber and embroidery, totally costs the huge fund hundreds of millions... the sound of gold and leather articles can be heard outside dozens of miles. The bandsmen of chord and pipe total 18,000. Firing torches are arranged greatly to lighten the sky and the earth. The grand Baixi is incomparable from the year dot."[4] by a large scale of rich and colorful music, Emperor Yang proudly showed the music of the Central Plains to the minorities, to make the ethnic minorities deeply feel the momentum of the magnificent music scene and the strong strength of the Central Plains, so that he achieved his purpose to make the minorities submit themselves to him without using any army. The arrangement of such music takes a lot of costumes, a variety of musical instruments and many music actors, but compared with the large-scale conflict and war that will expend huge military fee, lose many people's lives and property and cause social turmoil, these seem insignificant.

\section{CONCLUSION}

In summary, Emperor Yang who was called the tyrannical monarch in the world, had been careful before wining the throne, and then gave grant indulgence to music after wining the trust of Emperor Wen of Sui and his mother. So he had Confucians thought but advocated Laozhuang's Taoist ideology of indulgence to private desire and timely amusement. He loved rituals and rites, and was excessively indulged to music. As a monarch, Emperor Yang has his shortage; but as a scholar, he is successful. As he said: "people in the world think that I become the emperor because I inherited the legacy of the former emperor, and in fact, compared with scholars, I should also be the emperor.'[12] Emperor Yang is a literary talent, his creation of poetry style and his series of policies of music have a great impact on China's music culture. Particularly, it is valuable that he uses music to deal with the relations among ethnic minorities and reduce the unnecessary wars. At the same time, this is characterized by his application of music on dealing with the relations among ethnic minorities.

\section{REFERENCES}

[1] [Post-Jin] Liu Xu. " Book of Old Tang·Volume 53· the Third Biography -Biography of Li Mi " Beijing: Zhonghua Book Company P2215 1975.5

[2] "The Complete Translation of Twenty-Four Books of History", "Volume 3, Book of Sui-the Third Records of Emperors· Emperor Yang (the first)", Chinese Dictionary Publishing House, 2004.1.

[3] "The Complete Translation of Twenty-Four Books of History", "Volume 15, Book of Suithe Tenth Record-Music (the second)", Chinese Dictionary Publishing House, 2004.1

[4] "The Complete Translation of Twenty-Four Books of History", " Volume 76, Book of Sui the 41st Biography'Literature", Chinese Dictionary Publishing House, 2004.1

[5] "Poems of Pre-Qin, Han, Wei, Jin and Southern and Northern Dynasties", Zhonghua Book Company 1983. 9

[6] "The Collection of 103 Famous Poets in Han,Wei and the Six Dynasties", The Sixth Letter, Emperor Yang of Sui.

[7] "Zizhi Tongjian ·Volume 180. The Fourth Record of Sui the Sixth Year of Great Cause of Emperor Yang ", Zhonghua Book Company P5260

[8] "The Complete Translation of Twenty-Four Books of History", "Volume 84, Book of Sui·the 49th Biography·Turkic", Chinese Dictionary Publishing House, 2004.1

[9] "The Complete Translation of Twenty-Four Books of History", "Volume 4, Book of Sui · the Fourth Record of Emperors- Emperor Yang (the second)", Chinese Dictionary Publishing House, 2004.1

[10] "Zizhi Tongjian ·Volume 180·The Fourth Record of Sui· the Third Year of Great Cause of Emperor Yang", Zhonghua Book Company P5632

[11] "Zizhi Tongjian·Volume 180·The Fourth Record of Sui the Second Year of Great Cause of Emperor Yang", Zhonghua Book Company P5625

[12] "Zizhi Tongjian·Volume 182. The Fourth Record of Sui· the Ninth Year of Great Cause of Emperor Yang ", Zhonghua Book Company P5684 